\title{
Recent advances in the endoscopic management of variceal bleeding
}

Variceal haemorrhage may occur in up to $30 \%$ of patients with chronic liver disease. ${ }^{1}$ There is an estimated mortality in the region of $50 \%$ for the initial bleed ${ }^{2}$ and a hospital inpatient mortality for subsequent bleeds of $30 \%$.

Endoscopic techniques have been used to treat variceal haemorrhage for over 50 years, ${ }^{3}$ and are now accepted as the first line treatment for bleeding oesophageal varices ${ }^{45}$ and for their long term management. ${ }^{56}$ While injection sclerotherapy controls haemorrhage in approximately $90 \%$ of case, ${ }^{78}$ it is not applicable to the treatment of cardia/fundal gastric varices, ${ }^{9}$ and rebleeding may occur in up to $55 \% .{ }^{10}$ In the absence of a safe and effective alternative, complication rates of up to $40 \%$ and mortality rates of up to $2 \%$ have been accepted. ${ }^{11} 12$ In the light of these problems the search for better endoscopic treatments for the control of variceal haemorrhage continues.

\section{Tissue adhesives}

The tissue adhesives n-butyl-2-cyanoacrylate (histocryl) and isobutyl-2-cyanoacrylate (bucrylate) have been used to treat both oesophageal and gastric varices, ${ }^{13} 14$ with control of bleeding reported in about $90 \%$ of cases. The technique requires care, however, to ensure that the adhesive does not come into contact with the endoscope resulting in permanent damage to the endoscope channels. This risk can be minimised by applying silicone oil to the tip of the instrument and by mixing the adhesive with contrast to delay premature hardening. ${ }^{13}$ Rebleeding from post injection variceal ulceration, a major complication of injection sclerotherapy, ${ }^{15}$ is also reported with the tissue adhesives but is uncommon and easy to control. ${ }^{14}$ Two reported cerebrovascular accidents directly attributable to the tissue adhesives also give cause for concern, however, particularly in the context of their limited use. ${ }^{16}$

\section{Thrombin}

The use of human and bovine thrombin as a constituent of a thrombogenic cocktail has been widely reported. ${ }^{17} 18$ Thrombin injection does not need the technical precautions necessary for the tissue adhesives and is performed using the freehand injection technique as for injection sclerotherapy. In uncontrolled series, thrombin seems to be effective in controlling haemorrhage from both oesophageal and gastric varices. ${ }^{1920}$ Initial experience with gastric varices suggests that thrombin is an important addition to the haemostatic options in the treatment of bleeding fundal gastric varices which cannot be injected with conventional sclerosants. ${ }^{20}$ In addition, thrombin has a good safety profile with no reports of allergic reactions or thrombosis distant from the site of injection. ${ }^{19} 20$

\section{Endoscopic banding ligation}

Banding ligation was first reported in humans in $1990,{ }^{21}$ and is probably the most important development in endoscopic therapy, although long term evaluation is still awaited. The technique uses the same concepts as those for banding ligation of internal haemorrhoids. A cylinder, into which a second cylinder is inserted, is attached to the end of a forward viewing endoscope. A prestressed rubber band is already positioned at the distal end of the inner cylinder which is held in place by a trip wire running through the biopsy channel of the endoscope. The device is closely apposed to the variceal cord, suction is applied through the endoscope, and the band is released over the entrapped varix by pulling the trip wire. The varix eventually sloughs off leaving a small discrete ulcer.

There are three published reports of controlled comparison of injection sclerotherapy with banding ligation ${ }^{22-24}$ The results of these studies are broadly similar, with all three revealing no advantage for banding ligation over injection sclerotherapy for the control of active variceal haemorrhage.

The King's College study reported a statistically significant reduction in rebleeding in the banding cohort $30 \% v$ $53 \%),{ }^{23}$ while there was a trend towards less frequent rebleeding in the other two trials. There was a statistically significant reduction in the number of sessions required to achieve variceal obliteration in two of the trials $(3.4 v 4.9$ sessions; $39 v 72$ days), ${ }^{23}$ (4.1 $v 6 \cdot 2$ sessions), ${ }^{24}$ with a trend towards this in the other study.

In addition, one study reports a statistically significant reduction in complications in the banding ligation group $(2 \% v 22 \%),{ }^{22}$ although much of the difference is attributable to the high frequency $(12 \%)$ of oesophageal strictures in the sclerotherapy group. One of the other studies also reported fewer oesophageal strictures in the banding ligation group. ${ }^{24}$ This result should also be treated with caution as the oesophageal stricture rate in the study was also much higher than previously reported and may be related to the relatively high concentration of the sclerosing agent used ( $3 \%$ sodium tetradecyl sulphate mixed 1:1 with $50 \%$ dextrose).

Mortality data are incomplete because of the relatively short follow up (median less than 1 year), but one of the American studies does report improved survival in the banding ligation group $(28 \% v 45 \%) .{ }^{22}$ Detailed analysis of the data shows that most of the patients in this study were Child's class A or B, which contrasts with most assessments of injection sclerotherapy in which the majority of patients are Child's C. ${ }^{25}$ Evaluation of the Child's class $\mathrm{C}$ patients in this study shows no survival advantage for one treatment over the other, and it is the Child's C patients who usually present the management problem. ${ }^{26}$

These initial studies suggest that endoscopic banding ligation is a promising technique for the treatment of oesophageal varices, with the potential for faster variceal obliteration, fewer treatment related complications, and 
possibly less rebleeding and a reduction in mortality. Several caveats remain, however. While the technique is simple it is relatively cumbersome, with a session of banding ligation taking up to 30 minutes, ${ }^{27}$ and there are potential difficulties placing the $27 \mathrm{~cm}$ long overtube, particularly in the actively bleeding patient. One patient developed an oesophageal ulcer that was probably caused by the placement of the overtube. ${ }^{24}$ Furthermore, the field of vision is reduced by about $30 \%$ when the banding device is attached.

\section{Summary}

For the first time the endoscopist has more than one option for the management of gastro-oesophageal varices. It is now feasible to select the appropriate therapy on the basis of the clinical setting. Acute injection sclerotherapy remains a quick and simple technique for the control of active bleeding from oesophageal varices, and could be followed two or three days later by banding ligation. Earlier obliteration of varices with this technique may offer the prospect of only two or three sessions of therapy. The availability of the tissue adhesives and thrombin as injectates for fundal gastric varices provide the option of an initial attempt at endoscopic therapy in this high risk group.

The Department of Gastroenterology,

Chelsea and Westminster Hospital,

369 Fulham Road,

London SW10

Correspondence to: Dr Westaby.

1 Cales P, Pascal JP. Histoire naturelle des varices oesophagiennes au cours de la cirrhose (de la naissance a la rupture). Gastroenterol Clin et Biol 1988; 12 245-54.

2 Christensen $R$, Gaverholdt $\mathrm{H}$, Schlichting P, et al. Aspects of the natural history of gastrointestinal bleeding in cirrhosis and the effect of prednisolone. Gastroenterology 1981; 81: 944-52.

3 Crafoord C, Frencker P. New surgical treatment of varicose veins of the oesophagus. Acta Otolaryngol (Stockh). 1939; 27: 422-9.

4 Paquet K-J, Feussner H. Endoscopic sclerosis and esophageal balloon tamponade in acute haemorrhage from esophago-gastric varices: a prospective controlled randomized trial. Hepatology $1985 ; 5$ : 580-3.
5 Westaby D, MacDougall BRD, Williams R. Improved survival following injection sclerotherapy for oesophageal varices: final analysis of a controlled trial. Hepatology 1985; 5: 627-31.

6 Barsoum NS, Boulous FI, El-Robby A, et al. Tamponade and injection sclerotherapy in the management of bleeding oesophageal varices. Br 7 Surg 1982; 69: 76-8

7 Prindiville T, Trudeau W. A comparison of immediate versus delayed endoscopic injection sclerosis of bleeding oesophageal varices. Gastrointest Endosc 1986; 32: 385-8.

8 Westaby D, Hayes, P, Gimson A, et al. Controlled trial of injection sclerotherapy for active variceal bleeding. Hepatology 1989; 9: 274-7.

9 Merican I, Burroughs AK. Gastric varices. Eur f Gastroenterol Hepatol 1992; 4: 511-20.

10 MacDougall BRD, Westaby D, Theodossi A, Dawson JL, Williams R. Increased long-term survival in variceal haemorrhage using injection sclerotherapy. Results of a controlled trial. Lancet 1982; i: 124-7.

11 Schuman BM, Beckman JW, Tedesco FJ, Griffin JW, Assad R. Complications of injection sclerotherapy: a review. Am $\mathcal{f}$ Gastroenterol 1987; 82: 823-9.

12 Infante-Rivard C, Esnaola S, Villneuve JR. Role of endoscopic sclerotherapy in long-term management of variceal bleeding: a meta-analysis. Gastroenterology 1989; 96: 1087-92.

13 Soehendra N, Grimm H, Nam V, Berger N. N-Butyl-2-cyanoacrylate: a supplement to endoscopic sclerotherapy. Endoscopy 1987; 19: 221-4.

14 Ramond M-J, Valla D, Mosnier J-F, et al. Successful endoscopic obturation of gastric varices with butyl cyanoacrylate. Hepatology 1989; 10: 488-93.

15 The Copenhagen Esophageal Varices Sclerotherapy Project: Sclerotherapy after first variceal haemorrhage in cirrhosis. A randomized multicenter trial. N Engl f Med 1984; 311: 1594-600.

16 See A, Florent C, Lamy P, et al. Accidents vasculaires cerebaux apres obtuaration endoscopique des varices oesophagiennes par l'Isobutyl-2cyanoacrylate chez deux malades. Gastroenterol Clin Biol 1986; 10: cyanoacry

17 Kitano $\dot{S}$, Hashizume $M$, Yamaga $\mathrm{H}$, et al. Human thrombin plus 5 per cent ethanolamine oleate injected to sclerose oesophageal varices: a prospective randomized trial. Br f Surg 1989; 76: 715-8.

18 Lyons SD, Sugawa C, Geller ER, Vandenberg DM. Comparison of $1 \%$ sodium tetradecyl sulphate to a thrombogenic sclerosant cocktail for endoscopic sclerotherapy. Am Surg 1988; 54: 81-4.

19 Snobl J, Van Buuren HR, Van Blankestein M. Endoscopic injection therapy using thrombin: an effective and safe method for controlling oesophago gastric variceal bleeding. Gastroenterology 1992; 102: A891.

20 Williams SGJ, Peters RA, Westaby D. Thrombin - an effective treatment for fundal gastric varices? Gut 1993; 34 (suppl 1): S48.

21 Stiegmann GV, Goff JS, Sun JH, Hruza D, Reveille RM. Endoscopic ligation of esophageal varices. Am F Surg 1990; 159: 21-6.

22 Stiegmann GV, Goff JS, Michaletz-Onody PA, et al. Endoscopic sclerotherapy as compared with endoscopic ligation for bleeding esophageal varices. apy as compared with endoscopic ligati
$N$ Engl $₹$ Med 1992; 326: 1527-32.

23 Gimson AES, Ramage JK, Panos MZ, et al. Randomised trial of variceal banding ligation versus injection sclerotherapy for bleeding oesophageal varices. Lancet 1993; 342: 391-4

24 Laine L, El-Newihi HM, Migikovsky B, Sloane R, Garcia F. Endoscopic ligation compared with sclerotherapy for the treatment of bleedin esophageal varices. Ann Intern Med 1993; 119: 1-7.

25 O'Connor KW, Lehman G, Yune H, et al. Comparison of three nonsurgical treatments for bleeding oesophageal varices. Gastroenterology 1989; 96: 899-906.

26 Anonymous. Bleeding oesophageal varices: IST, EVL, or TIPS. Lancet 1992; 340: 515-6.

27 Stiegmann GV, Cambre T, Sun JH. A new endoscopic elastic band ligating device. Gastrointest Endosc 1986; 32: 230-3. 